Мудренко Наталія Володимирівна, аспірантка кафедри публічного управління та публічної служби Національної академії державного управління при Президентові України, дипломат, перший секретар Міністерства закордонних справ України, 01018, м. Київ, Михайлівська площа, 1, тел.: (044) 238-15-35, e-mail: natamudrenko@gmail.com, https//orcid.org/0000-0002-42459616

\title{
ЦИФРОВІ ІНСТРУМЕНТИ КООРДИНАЦІЇ ДІЯЛЬНОСТІ ОРГАНІВ ДЕРЖАВНОЇ ВЛАДИ У СФЕРІ ЗОВНІШНІХ ЗНОСИН
}

Анотація. Революційний розвиток інформаційно-комунікаційних технологій торкнувся майже усіх аспектів людського життя у XXI ст. Глобалізація та активне поширення нових засобів комунікацій сприяли поглибленню міжнародного співробітництва та зниженню витрат практично в усіх сферах життєдіяльності суспільства.

В сучасних умовах під впливом інформаційно-комунікаційних технологій відбувається трансформація системи органів зовнішніх зносин, вона стає все більш розгалуженою, багаторівневою, мережевою. У нинішній час лідери держав та урядів, міністерств і парламентських структур цілком самостійно виходять на прямі міжнародні зв'язки зі своїми безпосередніми візаві і партнерами, демонструючи тим самим нові умови міжнародних контактів та різні рівні впливу на формування національних зовнішньополітичних курсів. Значне зростання кількості міжнародних акторів, в тому числі - національних, та прискорення у часі усіх процесів $\epsilon$ викликами для системи органів зовнішніх зносин будь-якої держави світу. При цьому забезпечення “одноголосності" державної зовнішньої політики стає дедалі складнішим завданням за наявних підходів.

Водночас, в умовах безпрецедентних викликів та загроз внаслідок російської агресії “гібридного" характеру та теперішньою турбулентністю міжнародного безпекового середовища України, неузгодженість дій різних органів державної влади України на міжнародній арені призводить до значних негативних наслідків та іміджевих втрат держави.

У статті досліджуються можливості впровадження нових цифрових інструментів в управлінські процеси для підвищення ефективності координації діяльності органів державної влади України у сфері зовнішніх зносин на основі вивчення та аналізу досвіду провідних країн світу у цій сфері.

Ключові слова: дипломатія, цифрові інструменти, інформаційнокомунікаційні технології, публічне управління, сфера зовнішніх зносин. 
Mudrenko Natalia Volodymyrivna, postgraduate student of the Department of Public Administration and Public Service of the National Academy of Public Administration, diplomat, First Secretary of the Ministry of Foreign Affairs of Ukraine, 01018, Kyiv, Mykhaylivska square, 1, phone: (044) 238-15-35, e-mail: natamudrenko@gmail.com, https//orcid.org/0000-0002-4245-9616

\section{DIGITAL TOOLS FOR COORDINATION IN FOREIGN POLICY OF UKRAINE.}

Abstract. The revolutionary development of information and communication technologies affected almost any sphere of human life in the 21st century. The globalization and swift spread of new communications have helped to deepen international cooperation as well as to reduce costs in various spheres of social life.

Nowadays due to the influence of information and communication technologies, the governance system of external relations is transformed, it is becoming more and more branched, multileveled, networked. Presently, leaders of states and governments, ministries and parliamentary institutions directly contact their foreign vis-a-visas, thereby demonstrating the new reality of international relations as well as different levels of influence on the formation of national foreign policy courses. A significant increase in international actors, including national ones, and the acceleration in time of all processes, are the challenges for the governance system of external relations of any state in the world. At the same time, securing the "unanimity" of state foreign policy is becoming more difficult under the existing approaches.

As for Ukraine, which is facing unprecedented challenges and threats as a result of Russia's aggression of a "hybrid" nature as well as the current turbulence of international security environment, the inconsistency of the actions of various state authorities in the international arena leads to significant negative consequences and image losses.

The paper explores the facilities of using new digital tools in governance to improve the coordination of the activities of public authorities of Ukraine in foreign policy, based on the study and analysis of the experience of the leading countries in this field.

Keywords: diplomacy, external relations, digital tools, information and communication technologies, public administration, foreign policy.

Постановка проблеми. Революційний розвиток інформаційнотелекомунікаційних технологій (далі - IКТ) торкнувся майже усіх аспектів людського життя у XXI ст. Глобалізація та поширення IКТ сприяли поглибленню міжнародного співробітництва та зниженню витрат практично в усіх сферах життєдіяльності суспільства. Водночас, IКТ стали рушієм як 
позитивних змін - через удосконалення методів здійснення зовнішньої політики, ïi демократизації, надання рівних можливостей індивіду та іншим сучасним акторам міжнародних відносин щодо забезпечення власних інтересів; так і нових серйозних загроз - поширення кіберзлочинності, інформаційного тероризму та інших інформаційних зловживань.

Поява нових засобів комунікацій, які забезпечують миттєве поширення й передачу інформації, кардинально вплинула на сферу міжнародних відносин, для якої швидкість комунікації є визначальним фактором.

У нинішній час лідери держав та урядів, міністерств і парламентських структур цілком самостійно виходять на прямі міжнародні зв’язки зі своїми безпосередніми візаві і партнерами, демонструючи тим самим нові умови міжнародних контактів та різні рівні впливу на формування національних зовнішньополітичних курсів. 3 огляду на це, часом робиться доволі поспішний висновок про зменшення ролі i, навіть, занепад сучасної дипломатії у иï класичному вигляді. Проте варто зауважити, що пряме спілкування голів держав та урядів не відміняє потреби в дипломатії, а лише вносить корективи (щоправда, досить суттєві) до іiі завдань. Тут доречно згадати реакцію Лорда Пальмерстона, Прем’ер-міністра та Міністра закордонних справ Великої Британії на вперше отриману ним телеграму у 1850-х роках: “Боже мій, це кінець дипломатії!” [1].

Значне зростання кількості міжнародних акторів, в тому числі національних, та прискорення у часі усіх процесів є викликами для системи органів зовнішніх зносин будь-якої держави світу. При цьому забезпечення “одноголосності” державної зовнішньої політики стає дедалі складнішим завданням за наявних підходів.

Водночас в умовах безпрецедентних викликів та загроз внаслідок російської агресії “гібридного" характеру та теперішньою турбулентністю міжнародного безпекового середовища України, неузгодженість дій різних органів державної влади України на міжнародній арені призводить до значних негативних наслідків та іміджевих втрат держави.

Зазначене, в свою чергу, актуалізує пошук нових інструментів та необхідність удосконалення наявних механізмів управління, зокрема, координації діяльності органів державної влади України у сфері зовнішніх зносин.

Аналіз останніх досліджень і публікацій показав, що дослідженню впливу інформаційно-комунікаційних технологій на сучасну сферу зовнішніх зносин та дипломатичну службу України в рамках державної служби присвячено окремі наукові роботи вітчизняних науковців, зокрема: Н.Піпченко, Я.Турчин, Б.Гуменюка, Л.Літри, Ю. Кононенко, В.Бебика, О.Сагайдака. 
Метою цієї статті $є$ дослідження можливостей впровадження нових цифрових інструментів управління для підвищення ефективності координації діяльності органів державної влади України у сфері зовнішніх зносин.

Виклад основного матеріалу. В сучасних умовах під впливом активного поширення інформаційно-комунікаційних технологій відбувається трансформація системи органів зовнішніх зносин, вона стає все більш розгалуженою, багаторівневою, мережевою. Іншим важливим фактором $\epsilon$ неймовірне прискорення у часі усіх процесів, що, в свою чергу, вимагає якісного удосконалення управлінських функцій, зокрема, координації.

Вирішення цієї проблеми вбачається у впровадженні інноваційних інструментів інформаційно-телекомунікаційних технологій в управлінські процеси. У цьому контексті вважаємо за доцільне вивчити та проаналізувати досвід провідних країн світу з використання цифрових інструментів для удосконалення координації діяльності органів державної влади України у сфері зовнішніх зносин.

На сьогоднішній день дипломатичні служби більшості країн світу використовують можливості інформаційно-комунікаційних технологій для здійснення своїх функцій та комунікацій у сфері зовнішніх зносин.

Термін цифрова дипломатія, що позначає широке використання інформаційно-комунікаційних технологій для здійснення державними органами своїх функцій та комунікацій у сфері зовнішньої політики, вперше почали використовувати у країні, яку, по праву, можна назвати колискою цієї нової форми дипломатії - США.

Будучи світовим лідером у сфері ІКТ Сполучені Штати Америки ще 3 1996 року почали використання цифрових інструментів у зовнішньополітичних цілях, саме тоді світ побачив перший інтернет-журнал Washington Files, сформований інформаційним агентством США - ЮCIA (USIA, United States Information Agency) [2]. Перша робоча група 3 цифрової дипломатії була сформована в Держдепартаменті США у 2002 році.

Наразі арсенал цифрової дипломатії США $є$ одним 3 найширших $\mathrm{i}$ найбільш диверсифікованих в світі та демонструє свою високу ефективність.

Основні засади та принципи цифрової дипломатії США відображені в документі Держдепартаменту США «Державне управління в XXI ст.» $\left(21^{\text {st }}\right.$ Century Statecraft) [3]. Згідно документу, стрімкий розвиток інформаційних технологій і значне зростання користувачів Інтернету у світі вимагають від США зміни методів зовнішньої політики і іiї переорієнтації на можливості сучасних інформаційно-комунікативних технологій. Узагальнивши положення, можна дійти висновку, що всі проекти цифрової дипломатії США поділяються на дві категорії, що характеризуються основними функціями задля їх використання: як інструмент підвищення ефективності та канал зовнішньополітичного впливу. 
Вперше використання цифрових інструментів в дипломатичних цілях було затверджено у Стратегічному плані розвитку на 2011-1013 pp. Державного департаменту США [4]. В документі окремо були визначені основні цілі щодо використання соціальних медіа для підтримки позитивного іміджу держави, зокрема: використання соціальних медіа дозволяє розширити співробітництво та забезпечити обмін інформацією між внутрішніми та зовнішніми цільовими групами; використання "хмарних» технологій забезпечує глобальний доступ до інформації через надійну веб-інфраструктуру всім агентствам США, що працюють за кордоном; управління внутрішніми та зовнішніми IT-ресурсами сприяе ефективному обслуговуванню зовнішньополітичного відомства та дипломатичних представництв держави за кордоном. Виходячи 3 названих цілей Бюро управління інформаційних ресурсів Державного департаменту розробило інноваційні проекти та послуги щодо використання соціальних медіа у зовнішньополітичній практиці США.

Розробка та підтримка проектів була розподілена між трьома експертними групами: «DiploTech», «KL» та «P\&O». Група «DiploTech» забезпечувала підтримку ініціатив Державного секретаря щодо використання соціальних медіа для просування національних інтересів США через програми «Громадянське суспільство Web 2.0» та «Віртуальні послуги в сфері освіти»; група «KL» здійснювала управління такими продуктами як «Diplopedia», Communities@State, iNet Search та «Corridor»; група «P\&O» забезпечувала підвищення обізнаності серед співробітників відомства про використання соціальних медіа як інструменту підтримки зовнішньополітичної діяльності держави [5].

Крім того Бюро управління інформаційних ресурсів забезпечує підтримку низки тематичних програм, серед яких на окрему увагу заслуговує проект «Agile Response + Coordination». Це програма через яку надаються послуги громадянам США у разі техногенних катастроф, стихійних лих або відключення телекомунікаційної системи, збоїв в мережі та інших надзвичайних ситуаціях.

Проекти «Tech@State» та «TechCamp» $є$ платформами для діалогу дипломатів та експертів як з США, так і з усього світу щодо вивчення інноваційних шляхів використання сучасних Інтернет-технологій у зовнішньополітичній діяльності. 3 метою полегшення виконання функціональних обов'язків для дипломатів розроблено пошуковий інструмент «SearchState», за допомогою якого можна легко знайти релевантну інформацію в базах даних Департаменту, а також панель інструментів «Current», яка поєднує всі внутрішні сервіси відомства в єдине ціле та забезпечує доступ до різноманітної зовнішньої інформації.

3 метою покращення комунікації та координації всередині системи державного управління США, Бюро управління інформаційних ресурсів Державного департаменту розробило соціальну мережу «Corridor» [6]. Мережа 
«Corridor» орієнтована на користування нею співробітниками Держдепартаменту та представниками інших владних структур США. «Corridor» побудований на платформі WordPress 3 відкритим кодом, яка працює за захищеним брандмауером [7]. За принципом Facebook, i LinkedIn, y мережі створюються профілі користувачів, надається можливість публікувати звіти про професійні досягнення, розширювати базу професійних контактів, ознайомлюватись 3 досвідом діяльності колег з інших країн, формувати групи для обговорення професійних тематик.

Іншим цифровим інструментом, що слугує платформою для співробітників Держдепартаменту для обговорення та впровадження інновацій в дипломатичну практику 3 можливістю отримати цільове фінансування $\epsilon$ внутрішній блог The Sounding Board.

Вагомий внесок у розвиток внутрішньої обізнаності вносить онлайн енциклопедія «Diplopedia» - внутрішня інформаційна-довідкова платформа Держдепартаменту США. Так само, як люди публікують та редагують статті в «Вікіпедії», співробітники Держдепартаменту використовують «Diplopedia» для створення та постійного оновлення широкої інформаційної бази для обміну знаннями та досвідом щодо програм та діяльності в рамках Департаменту, а також висвітлення міжнародних питань.

Окрім цього, діють також спеціальні програми із залучення молодих спеціалістів та досвідчених професіоналів у дистанційному режимі, зокрема: Програма віртуальних студентських стажувань (Virtual Student Foreign Service). Дана програма є ініціативою Держдепартаменту в рамках програми із технологічного залучення до державної служби ініціативної та активної молоді 3 метою винайдення нових форм функціонування дипломатичної системи. Студенти отримують можливість пройти дев’ятимісячне віртуальне стажування в офісах Держдепартаменту США. Додатково функціонує програма віртуальних співробітників (Virtual Fellows Program), що дозволяє Держдепартаменту отримувати переваги від залучення компетентних консультантів та науковців у різноманітних проектах як на території США, так і у закордонних місіях [8].

Окрема робота ведеться зі створення віртуальних презентаційних постів, які допомагають посольствам або консульствам США мобілізувати інструменти інформаційної роботи для поглиблення взаємодії з громадянами країн, в яких США не мають дипломатичного представництва, зокрема, нині існує близько 40 віртуальних представництв США за кордоном.

На сьогоднішній день Бюро управління інформаційних ресурсів Державного департаменту у рамках виконання Програми «FY 2018 - 2022 Department Cloud Strategy» переводить усі свої сервіси в хмарні середовища [9]. Таким чином, використання цифрових інструментів у зовнішньополітичній діяльності США значно розширило можливості та підвищило ефективність роботи, спрямованої на формування позитивного 
іміджу країни та політичної влади, поширення інформації для наявної i потенційної аудиторії, забезпечення безпосереднього спілкування з індивідами або різними групами у різних куточках світу, а також збільшення обсягу якісної інформації на офіційних акаунтах державних та недержавних інституцій.

Активізація зусиль Свропейського Союзу в напрямку зміцнення статусу самостійного актора на міжнародній арені сприяла створенню Свропейської служби зовнішніх справ, що дозволило посилити координацію європейської зовнішньої політики та забезпечити ефективне представництво $€ C$ за кордоном. Оскільки європейське зовнішньополітичне відомство не замінює національні міністерства закордонних справ, а лише доповнює дипломатичні представництва країн-членів СС, то важливого значення набула підтримка ефективної комунікації з широкою громадськістю засобами соціальних мереж, зокрема, створено близько 75 офіційних акаунтів зовнішньополітичного відомства та представництв СС закордоном у соціальних мережах, при цьому, крім всесвітньо популярних профілів у Facebook, Twitter та YouTube, відкрито тематичні акаунти у національних соціальних медіа, як наприклад, Sina Weibo, Tencent Weibo, Vk.Com, Flickr aбо Storify, що свідчить про бажання СС спілкуватись $з$ аудиторією не лише рідною мовою, але й враховувати культурні та ментальні особливості різних регіонів світу [10]. Для підтримки зовнішньополітичної діяльності через соціальні медіа Свропейський Союз намагається задіяти механізми узгодження та обміну інформацією щодо спільних загальноєвропейських інтересів, вироблення «спільної позиції» зі сприйняття та аналізу різних міжнародних подій, узгодження позицій національних урядів з європейською політичною поведінкою щодо визначення цілей та пріоритетів ЄС відносно третіх країн, якщо дипломатичні інструменти виявляються недостатніми для забезпечення спільної зовнішньої та безпекової політики СС.

Висновки дослідження. Отже, використання широкого арсеналу цифрових інструментів для здійснення державними органами своїх функцій у сфері зовнішніх зносин сприяє покращенню комунікації та координації всередині системи державного управління, розширює можливості у зовнішньополітичній діяльності та, в цілому, забезпечує підвищення ефективності роботи.

Виходячи із викладеного, вважаємо, що впровадження нових цифрових інструментів управління в Україні сприятиме підвищенню ефективності координації діяльності органів державної влади України, зокрема, у сфері зовнішніх зносин.

\section{Jimepamypa:}

1. Digital diplomacy/e-diplomacy/cyber-diplomacy. Електронна платформа Diplo. Режим доступу: https://www.diplomacy.edu/e-diplomacy\#ff1-4

2. Гуцал С. А. Публічна дипломатія як сучасний пріоритет зовнішньої політики держави. Стратегічні пріоритети. 2010. № 3(16). С. 106-114. 
3. $21^{\text {st }}$ Century Statecraft. U.S. Department of State. Archive. Режим доступу: https://2009-2017.state.gov/statecraft/overview/index.htm

4. IT Strategic Plan: Fiscal Years 2011-2013 - Digital Diplomacy // Bureau of Information Resource Management. [Електронний ресурс] - Режим доступу: https://20092017.state.gov/m/irm/rls/148572.htm

5. Піпченко Н.О. Цифрова дипломатія як інструмент зовнішньополітичної діяльності США. Міжнародні відносини. Серія «Політичні науки». 2015. № 5. С. 15-26.

6. Lipowicz Alice, State employees' social networking site just around the Corridor. // GCN.com [Електронний ресурс] - Режим доступу: https:/gcn.com/articles/2011/04/22/statedept--preparing-to-launch-corridor-social-network-for-employees-only.aspx

7. Gadi Ben-Yehuda, Peering down the Corridor: The New Social Network’s Features and Their Uses. // IBM Center for the Business of Govemment. [Електронний ресурс] - Режим доступу: http://www.businessofgovernment.org/blog/peering-down-corridor-new-social-networksfeatures-and-their-uses

8. Піпченко Н.О. Традиції та інновації зовнішньополітичної діяльності США, СС та РФ. // Нова парадигма. - 2013. - Вип. 116. - с. 89-96.

9. IT Strategic: Plan Fiscal Years 2019 - 2022 - Digital Diplomacy // Bureau of Information Resource Management. [Електронний ресурс] - Режим доступу: https://www.state.gov/wp-content/uploads/2019/04/FY-2019-2022-ITSP_FINAL-508._withSignature.pdf

10. The EEAS and Social Media // The European Union official website. [Електронний pecypc] - Режим доступу: https://eeas.europa.eu/headquarters/headquartershomepage/9005/eeas-and-social-media_en

\section{References:}

1. Digital diplomacy/e-diplomacy/cyber-diplomacy. (n.d.). www.diplomacy.edu. Retrieved from https://www.diplomacy.edu/e-diplomacy\#ff1-4 [in English].

2. Hutsal, S. A. (2010). Publichna dyplomatiya yak suchasnyy priorytet zovnishnoi polityky derzhavy [Public diplomacy as a contemporary priority of the state's foreign policy]. Stratehichni priorytety - Strategic priorities, 3(16), 106-114 [in Ukrainian].

3. 21st Century Statecraft. (n.d.). 2009-2017.state.gov. Retrieved from https://20092017.state.gov/statecraft/overview/index.htm [in English].

4. IT Strategic Plan: Fiscal Years 2011-2013 - Digital Diplomacy. (2010). 20092017.state.gov. Retrieved from https://2009-2017.state.gov/m/irm/rls/148572.htm [in English].

5. Pipchenko, N.O. (2015). Tsyfrova dyplomatiya yak instrument zovnishnopolitychnoyi diyalnosti SSHA [Digital diplomacy as a tool of the US foreign policy]. Mizhnarodni vidnosyny. Seriya «Politychni nauky» - International relations. Political Science Series, 5, 15-26 [in Ukrainian].

6. Lipowicz, A. (2011). State employees' social networking site just around the Corridor. gcn.com. Retrieved from https://gcn.com/articles/2011/04/22/state-dept--preparing-to-launchcorridor-social-network-for-employees-only.aspx [in English].

7. Ben-Yehuda, G. (2011). Peering down the Corridor: The New Social Network’s Features and Their Uses. www.businessofgovernment.org. Retrieved from http://www.businessofgovernment.org/blog/peering-down-corridor-new-social-networksfeatures-and-their-uses [in English].

8. Pipchenko, N.O. (2013). Tradytsiyi ta innovatsiyi zovnishnopolitychnoyi diyalnosti SSHA, YES ta RF [Traditions and innovations of the foreign policy of the USA, the EU and the Russian Federation]. Nova paradyhma - New paradigm, 116, 89-96 [in Ukrainian]. 
9. Information Technology Strategic Plan. Fiscal Years 2019 - 2022. (2019). www.state.gov. Retrieved from https://www.state.gov/wp-content/uploads/2019/04/FY-20192022-ITSP_FINAL-508._with-Signature.pdf [in English].

10. The EEAS and Social Media. (2016). eeas.europa.eu. Retrieved from https://eeas.europa.eu/headquarters/headquarters-homepage/9005/eeas-and-social-media_en [in English]. 